\section{ONE LONG ARGUMENT}

ERNST MAYR. 1991. Harvard University Press, Cambridge. 195 pp.

An abstract published by Charles Darwin in 1859 changed the world. The great importance of his work, especially "The Origin of Species," draws attention to Darwin, a shy, reserved and upstanding character. If you were in any way hesitant about giving Darwin his due before, I suggest you read Ernst Mayr's latest book, One Long Argument. It will impress upon the reader that Darwin had a "brilliant mind, great intellectual boldness, and an ability to combine the best qualities of a naturalist-observer, philosophical theoretician, and experimentalist."

This book, 195 pages of text, glossary, references and index (with a few photographs of the big names in early evolutionary thinking) is about the philosophical and historical development of evolutionary thinking since Darwin. The book is also a description of the gross anatomy of Darwin's compound evolutionary theory and how it is defined from various viewpoints. Mayr also emphasises the role and importance of Thomas Malthus (1766-1834), an economist whose "Essay on the Principle of Population" gave Darwin and Alfred Russell Wallace some interesting aspects to look at. There is also a discussion of $A$. Weismann (1834-1914), a German evolutionist, and his effect on Darwin's thinking. It is sad to say, Weismann is often remembered today as the one who cut tails off mice. Later, Mayr follows the evolutionary synthesis which occurred between 1936 and 1950, when "unification of a previously badly split field" began and naturalists and geneticists integrated their ideas.

Early in the book the attacks on evolutionary theory from "creationists" are discussed in detail. Opposing Darwin, or at least disagreeing with his apparent downplaying of the importance of God, were fellow scientists Henslow, Sedgewick, Agassiz, and Owen, to name a few. Their opposition was based primarily on their religious beliefs, some agreeing with many aspects of Darwin's theory. It is interesting to note Mayr's comments on current attacks: "claims [today] that Darwinism is obsolete have been made in numerous articles and books also by several non-biologists, whose arguments, though non-religious are based on such ignorance of evolutionary biology that it is not worthwhile to provide references to their writings."

The final chapter sums up Darwin's five sub-theories: evolution, common descent, development of diversity, gradualism, and finally, natural selection. Though not all were embraced by biologists immediately, years of work have substantiated Darwinian evolution and pushed it forward.

Finally, some may ask, should we encourage another book on Darwin? Haven't we read enough about him? I know of no other book that explains Darwin and Darwinism in such a passionate, knowledgeable, and clearcut fashion as One Long Argument by Ernst Mayr.

Reviewed by Tim Tokaryk, Saskatchewan Museum of Natural History, 2340 Albert Street, Regina, Saskatchewan. S4P 3V7 


\section{A DICTIONARY OF ETHOLOGY}

KLAUS IMMELMANN and COLIN BEER. 1989. Harvard University Press, Cambridge, Massachusetts. xiii + 336 pp. $\$ 35.00$ (US)

This dictionary is, in part, an expanded version and English translation of three earlier compilations of ethological terms originally written in German by the late Klaus Immelmann.

The authors state that the main function of this dictionary is to explain the more important terms used in the study of animal behaviour and to survey their range of application. To this end they have excluded highly technical terms that apply only to one or a few species - terms that might only serve the needs of specialists. Each entry in the dictionary is boldfaced, followed by a capsule definition consisting of words that are synonymous or closely related in meaning to the term being defined. An explanation of the term is then given followed by examples and, in many instances, by cross-references to one or more other terms. In using examples to support their definitions of terms, the authors have chosen to consider the higher vertebrates because, they state, "This is more than a reflection of our own research interests, which have been mainly in the area of bird behaviour; it is a consequence of the fact that, from the beginning, observations and experiments on birds and mammals have supplied a high proportion of ethology's basic needs ideas and technical concepts." The cross-references appear in bold uppercase letters in parentheses. Throughout the text the authors of other publications are cited and then listed with their publications in a bibliography at the end of the book. Unfortunately, there are nine authors and references listed in the bibliography which do not appear within the compilation. Further, two errors in the year of publication occur in the compilation and the bibliography.

In reviewing this compilation of more that 1,000 entries, some 700 term descriptions, and more than 800 cross-references, I soon learned that most of the term definitions were supported by relatively lengthy and very informative in-depth discussions and examples. Rather than being just a dictionary, this compilation appears to be more encyclopedic in its approach and, as such, an important and useful reference for professional and serious students of animal behaviour. As an addition to an office or home library, this compilation should be a great asset to those who enjoy observing the behaviour of animals and desire to write and publish their observations, and to those who wish to define terms encountered when reading ethological literature.

Reviewed by George J. Mitchell, Department of Biology, University of Regina, Regina, Saskatchewan. S4S OA2 